Environmental Research Journal 4 (3): 244-250, 2010

ISSN: 1994-5396

(C) Medwell Journals, 2010

\title{
Biosorption of Chromium (VI) Using Rice Husk Ash and Modified Rice Husk Ash
}

\author{
Jureeporn Wongjunda and Panjai Saueprasearsit \\ Faculty of Environment and Resource Studies, Mahasarakham University, \\ Mahasarakham 40000, Thailand
}

\begin{abstract}
The purpose of this research was to investigate the adsorption ability and determine the suitable condition for adsorption of Chromium ( $\mathrm{Cr}(\mathrm{VI})$ ) in synthetic wastewater by Rice Husk Ash (RHA) and $0.1 \mathrm{NaOH}$ modified RHA (MRHA). Adsorption abilities of the adsorbents in various conditions were examined in batch experiment. Contact time, $\mathrm{pH}$, adsorbent dose and initial $\mathrm{Cr}(\mathrm{VI})$ concentration were varied to perform the adsorption conditions. The results indicated that all adsorption parameters affected to the adsorption of $\mathrm{Cr}(\mathrm{V})$ by RHA and MRHA. At the suitable condition ( $\mathrm{pH}$ 2, contact time $180 \mathrm{~min}$, room temperature, initial $\mathrm{Cr}(\mathrm{VI})$ concentration $10 \mathrm{mg} \mathrm{L}^{-1}$, adsorbent dose $40 \mathrm{~g} \mathrm{~L}^{-1}$, adsorbent size of $250-500 \mu \mathrm{m}$ ), the adsorption abilities of RHA and MRHA were 0.49 and $0.84 \mathrm{mg} \mathrm{g}^{-1}$ with removal efficiencies of 59.12 and $81.39 \%$, respectively. Langmuir isotherm was found to better fit the experiment data rather than Fruendlich isotherm. As waste-recycle products, RHA and MRHA has been proved to be an effective adsorbent for $\mathrm{Cr}(\mathrm{VI})$ removal.
\end{abstract}

Key words: Rice husk ash, $\mathrm{Cr}(\mathrm{VI})$, modification, adsorption isotherms, adsorption parameters, Thailand

\section{INTRODUCTION}

Chromium in the hexavalent form $\mathrm{Cr}(\mathrm{VI})$ is a significant heavy metal is widely used in various industries such as leather tanning, electroplating, metal processing and wood preservatives including paint and pigment (Raji and Anirudhan, 1997; Garg et al., 2004). $\mathrm{Cr}(\mathrm{VI})$ poisoning in humans targets the nasal septum (Khatoon et al., 2009) and can causes lung cancer (Hughes et al., 1994) and skin ulcerations (McCarron et al., 2000). As a result, many researchers have tried to determine cost effective and economic method for removal of this chemical. Well established methods include filtration, chemical precipitation, adsorption, electrodeposition and membrane systems and an ion exchange process.

There are drawbacks to these methods. The chemical precipitation and reduction methods requires additional separation techniques for the treatment and disposal of the high quantities of waste metal residual sludge that is produced. These additional separation techniques use a lot of treatment chemicals and the residual $\mathrm{Cr}(\mathrm{VI})$ concentration required in the treated wastewater is not achieved because of the structure of the precipitates. The application of membrane systems for wastewater treatment has major problems like membrane scaling, fouling and blocking. The ion exchange process has a drawback in the high cost of the resin, while the electrodeposition method is more energy intensive than other methods. Among these methods adsorption is one of the most economically favorable and a technically simple (Karthikeyan et al., 2005). Conventionally, activated carbons have been found to be an effective adsorbents for recovering $\mathrm{Cr}(\mathrm{VI})$ from wastewater (Aggarwal et al., 1999).

However, the process is expensive and uses high amount of energy in its production, which has led to the search for new strategies for developing low-cost materials with a good capacity for $\mathrm{Cr}(\mathrm{VI})$ removal (Saueprasearsit et al., 2010; Guo et al., 2009; Karthikeyan et al., 2005; Khezami and Capart, 2005), such as bagasse fly ash (Gupta and Ali, 2004), rice bran (Singh et al., 2005), maple saw dust (Yu et al., 2003), coconut husk, palm pressed fibers (Tan et al., 1993) and various other low-cost biological wastes. Rice husk is an important Thai agricultural waste which is produced in high quantity each year.

It is usually used as a fuel or a raw material in many industries such as fertilizer manufacturing and bio-coal production including biomass power plant. Its utilization as a fuel produces rice husk ash which may cause damage to human health and the environment, such as occurring particulate matter, destroying good landscape, etc. Consequently, rice husk ash which is an industrial waste

Corresponding Author: Panjai Saueprasearsit, Faculty of Environment and Resource Studies, Mahasarakham University, Mahasarakham 40000, Thailand 
from the Roi-Et Green Power Plant biomass power plant in Roi-Et, Thailand was used as an adsorbent in this research. This research investigated the mechanism of $\mathrm{Cr}$ (VI) adsorption, adsorption capacity and adsorption isotherm of rice husk ash and modified husk ash. The MRHA was developed to enhance of the adsorption capacity of rice husk ash. The effects of adsorption parameters as $\mathrm{pH}$, contact time and initial $\mathrm{Cr}(\mathrm{VI})$ concentration were examined.

Preparation of Rice Husk Ash (RHA): The RHA from Roi-et Green Power Plant was washed with distilled water until the $\mathrm{pH}$ was constant, dried in an oven at $105^{\circ} \mathrm{C}$ for $24 \mathrm{~h}$. It was cooled in incubator and determined its size distribution by USA Standard Sieve $(\leq 125,125-250$, $250-500,500-600,600-710$ and $710-850 \mu \mathrm{m}$ ). The size distribution results are shown in Table 1 . Thus, studied particle size was $250-500 \mu \mathrm{m}$. Finally, RHA was size separated and stored in plastic containers for the future experiments.

Preparation of Modified Rice Husk Ash (MRHA): The modification of rice husk ash done by, the RHA was mixed with $0.1 \mathrm{MNaOH}(1: 20)$ for $30 \mathrm{~min}$, after treatment with $0.1 \mathrm{M} \mathrm{NaOH}$, the excess $\mathrm{NaOH}$ form the Modified Rice Husk Ash (MRHA) was washed with distilled water until the $\mathrm{pH}$ was constant and then it was dried in an oven at $105^{\circ} \mathrm{C}$ for $24 \mathrm{~h}$.

Preparation of synthetic Cr(VI) wastewater: Aqueous solutions $\left(1,000 \mathrm{mg} \mathrm{L}^{-1}\right)$ of $\mathrm{Cr}(\mathrm{VI})$ was prepared by dissolving $\mathrm{K}_{2} \mathrm{Cr}_{2} \mathrm{O}_{7}(\mathrm{~s})$ in distilled water and diluted to get the desired concentration as $5-30 \mathrm{mg} \mathrm{L}^{-1}$. The $\mathrm{Cr}(\mathrm{VI})$ concentrations were measured by Atomic Adsorption Spectrophotometer (AAS) (AA-6200, Shimadzu).

Effects $\mathrm{pH}$, contact time and initial $\mathrm{Cr}$ (VI) concentration Effect of $\mathbf{p H}$ : The effect of system $\mathrm{pH}$ was studied by varying the initial $\mathrm{pH}(2-7)$ of $50 \mathrm{~mL} \mathrm{Cr}$ (VI) solutions at concentration $10 \mathrm{mg} \mathrm{L}^{-1}$ by adjusting the $\mathrm{pH}$ with $0.1 \mathrm{M}$ $\mathrm{NaOH}$ and $0.1 \mathrm{M} \mathrm{HCl}$. The RHA dosage of $10 \mathrm{~g} \mathrm{~L}^{-1}$ was mixed with the solutions in a $250 \mathrm{~mL}$ flask and then shaking the mixtures at $120 \mathrm{rpm}$ and the room temperature. After shaking the flasks for $30 \mathrm{~min}$, the reaction mixtures were separated by filtering. Then, the residue $\mathrm{Cr}(\mathrm{VI})$ in the filtered solutions were measured by AAS. In addition, the $\mathrm{pH}$ of aqueous solution was also analyzed by the $\mathrm{pH}$ meter (Classic g 24, Scientific).

The absorbent was changed from RHA to be MRHA for studying the effect of $\mathrm{pH}$ on $\mathrm{Cr}(\mathrm{VI})$ removal by MRHA. The percent of $\mathrm{Cr}$ (VI) adsorption was determined by the following equation:

\begin{tabular}{lccc}
\multicolumn{4}{l}{ Table 1: Size distribution of rice husk ash } \\
\hline Sieve number & Size $(\mu \mathrm{m})$ & Quantity $(\mathrm{g})$ & By weight $(\%)$ \\
\hline 270 & $\leq 125$ & 38.92 & 19.78 \\
120 & $125-250$ & 46.08 & 23.42 \\
60 & $250-500$ & 60.21 & 30.60 \\
35 & $500-600$ & 14.49 & 7.36 \\
30 & $600-710$ & 13.72 & 6.97 \\
25 & $710-850$ & 23.31 & 11.84 \\
Total & & 196.73 & 100.00 \\
\hline
\end{tabular}

$$
\text { Cr(VI)adsorption }(\%)=\left[\frac{\mathrm{C}_{0}-\mathrm{C}_{\mathrm{e}}}{\mathrm{C}_{0}}\right] \times 100
$$

where, $\mathrm{C}_{0}$ and $\mathrm{C}_{\mathrm{e}}$ are the initial and equilibrium concentration $\left(\mathrm{mg} \mathrm{L}^{-1}\right)$, respectively.

Effect of contact time: The experiments were carried out by using $50 \mathrm{~mL} \mathrm{Cr}(\mathrm{VI})$ solution at $10 \mathrm{mg} \mathrm{L}^{-1}$ which adjusted $\mathrm{pH}$ to the optimal $\mathrm{pH}$. The RHA dosage of $10 \mathrm{~g} \mathrm{~L}^{-1}$ was mixed with the solutions in a $250 \mathrm{~mL}$ flask and then shaking the mixtures at $120 \mathrm{rpm}$ and the room temperature. After shaking the flask for $0,10,30,60,180$ and $360 \mathrm{~min}$, the reaction mixtures were separated by filtering.

Then, the residue $\mathrm{Cr}$ (VI) in the filtered solutions were measured by the AAS and $\mathrm{pH}$ meter, respectively. The absorbent was changed from RHA to the MRHA for studying the effect of contact time on $\mathrm{Cr}(\mathrm{VI})$ removal by MRHA.

Effect of adsorbent dosage: The experiments were carried out by using $50 \mathrm{~mL} \mathrm{Cr}$ (VI) solution at concentrations $10 \mathrm{mg} \mathrm{L}^{-1}$ which adjusted $\mathrm{pH}$ to the optimal $\mathrm{pH}$. The RHA dosage $\left(10,20,30,40\right.$ and $\left.50 \mathrm{~g} \mathrm{~L}^{-1}\right)$ was mixed with the solutions in a $250 \mathrm{~mL}$ flask and then shaking the mixtures at $120 \mathrm{rpm}$ and the room temperature. After shaking the flask for the suitable contact time, the reaction mixtures were separated by filtering. Then, the residue $\mathrm{Cr}(\mathrm{VI})$ in the filtered solutions were measured by the AAS and $\mathrm{pH}$ meter, respectively. The absorbent was changed from RHA to the MRHA for studying the effect of initial Cr(VI) concentration on $\mathrm{Cr}$ (VI) removal by $\mathrm{MRHA}$.

Effect of initial $\mathrm{Cr}(\mathrm{VI})$ concentration: The experiments were carried out by using $50 \mathrm{~mL} \mathrm{Cr}(\mathrm{VI})$ solution at concentrations $10-30 \mathrm{mg} \mathrm{L}^{-1}$ which adjusted $\mathrm{pH}$ to the optimal $\mathrm{pH}$. The optimal RHA dosage was mixed with the solutions in a $250 \mathrm{~mL}$ flask and then shaking the mixtures at $120 \mathrm{rpm}$ and the room temperature. After shaking the flask for the appropriate contact time, the reaction mixtures were separated by filtering. Then, the residue $\mathrm{Cr}(\mathrm{VI})$ in the filtered solutions were measured by the AAS and $\mathrm{pH}$ meter, respectively. The absorbent was changed from RHA to the MRHA for studying the effect of initial $\mathrm{Cr}$ (VI) concentration on $\mathrm{Cr}$ (VI) removal by MRHA. 
Sorption isotherms (Guo et al., 2009): Adsorption isotherms describe how adsorbates interact with adsorbents and are critical in optimizing the use of adsorbents. Adsorption efficiency is commonly determined by the extent of solute adsorbed from the solution. The amount of adsorbate per unit mass of adsorbent at equilibrium $\left(\mathrm{q}_{\mathrm{e}}, \mathrm{mg} \mathrm{g}^{-1}\right.$ ) and the adsorbate equilibrium concentration $\left(\mathrm{C}_{\mathrm{e}}, \mathrm{mg} \mathrm{L}^{-1}\right)$ allows plotting the adsorption isotherm versus and the mathematical models can be used to describe and characterize the adsorption process. In this research, two isotherm models were used to study the equilibrium sorption as Langmuir and Freundlich models. The Langmuir model assumes that the uptake of metal ions on a homogenous surface by monolayer adsorption without any interaction between adsorbed ions. The Langmuir model for equilibrium ion removed is given by:

$$
\mathrm{q}_{\mathrm{e}}=\frac{\mathrm{q}_{\max } \mathrm{bC}_{\mathrm{e}}}{\left(1+\mathrm{bC}_{\mathrm{e}}\right)}
$$

where, $q_{e}$ is the metal ions concentration on the adsorbent at equilibrium (mg of metal ion $/ \mathrm{g}$ of adsorbent), $\mathrm{q}_{\max }$ is the maximum metal uptake per unit mass of adsorbent ( $\mathrm{mg}$ $\left.\mathrm{g}^{-1}\right)$. $\mathrm{b}$ is Langmuir constant $\left(\mathrm{L} \mathrm{mg}^{-1}\right)$ related to energy of sorption which reflects quantitatively the affinity between the adsorbent and metal ions. The values of $\mathrm{q}_{\max }$ and $\mathrm{b}$ are the characteristics of the Langmuir model. They can be determined by linearizing Eq. 2 as shown in Eq. 3:

$$
\frac{C_{e}}{q_{e}}=\frac{1}{q_{\max } b}+\frac{C_{e}}{q_{\max }}
$$

Therfore, a plot of $\mathrm{C}_{e} / \mathrm{q}_{\mathrm{e}}$ versus $\mathrm{C}_{e}$, gives a straight line of slope $\mathrm{I} / \mathrm{q}_{\max }$ and intercept $\mathrm{I} / \mathrm{q}_{\max } \mathrm{b}$ (Fig. 1 and 2), which shows that the adsorption of $\mathrm{Cr}(\mathrm{VI})$ follow by RHA and MRHA Langmuir isotherm model. The Langmuir parameters, $q_{\max }$ and $b$ are calculated from the slope and intercept of the graphs and are shown in Table 1.

On the other hand, the Freundlich model is chosen to evaluate parameters associated to the sorption behavior. The equation is commonly represented by:

$$
\mathrm{q}_{\mathrm{e}}=\mathrm{K}_{\mathrm{f}} \mathrm{C}_{\mathrm{e}}^{1 / \mathrm{n}}
$$

where, $\mathrm{K}_{\mathrm{f}}$ and $\mathrm{n}$ are Freundlich constants, indicating the adsorption capacity and the adsorption intensity respectively. The above equation is rearranged in linear form to give:

$$
\ln \mathrm{q}_{\mathrm{e}}=\ln \mathrm{K}_{\mathrm{f}}+\frac{1}{\mathrm{n}} \ln \mathrm{C}_{\mathrm{e}}
$$

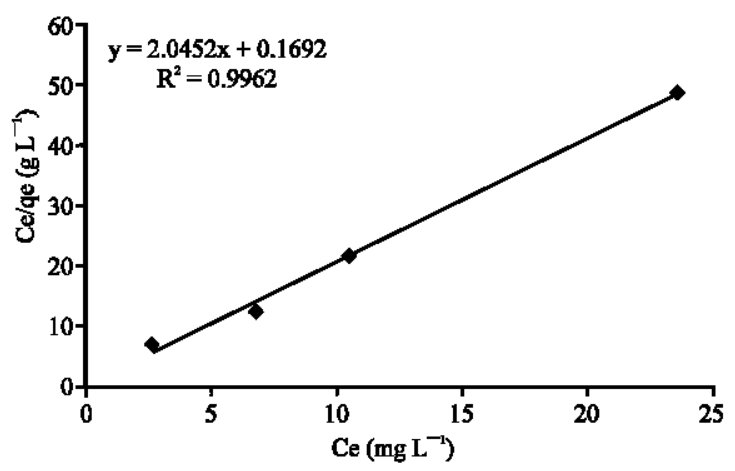

Fig. 1: Langmuir isotherm for the adsorption of $\mathrm{Cr}(\mathrm{VI})$ by RHA

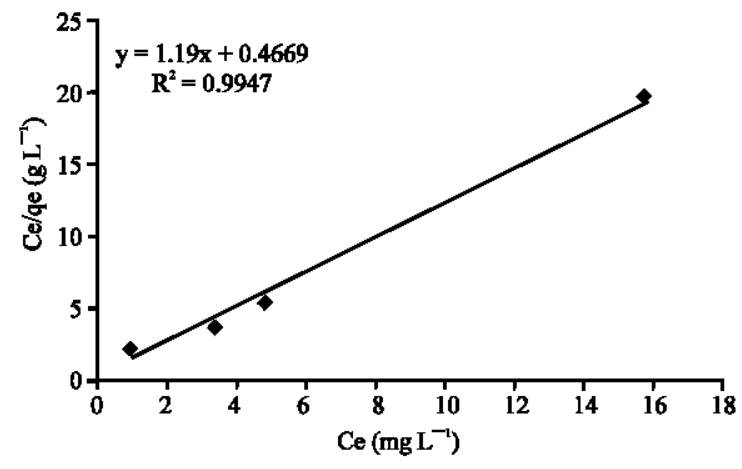

Fig. 2: Langmuir isotherm fir the adsorption of $\mathrm{Cr}(\mathrm{VI})$ by

\begin{tabular}{|c|c|c|c|c|c|}
\hline \multicolumn{3}{|c|}{ Langmuir isotherm } & \multicolumn{3}{|c|}{ Fruendlich isotherm } \\
\hline $\begin{array}{l}\mathrm{q}_{\max } \\
\left(\mathrm{mg} \mathrm{g}^{-1}\right)\end{array}$ & $\begin{array}{l}\mathrm{b} \\
\left(1 \mathrm{mg}^{-1}\right)\end{array}$ & $\mathrm{R}^{2}$ & $\begin{array}{l}\mathrm{K}_{\mathrm{f}} \\
\left(\mathrm{mg} \mathrm{g}^{-1}\right)\end{array}$ & $\begin{array}{l}n \\
(-)\end{array}$ & $\mathrm{R}^{2}$ \\
\hline 0.49 & 12.09 & 0.99 & 0.39 & 11.20 & 0.3495 \\
\hline 0.84 & 2.55 & 0.9947 & 0.50 & 4.08 & 0.6363 \\
\hline
\end{tabular}
MRHA

Table 2: Langmuir and Fruendlich isotherm constants for adsorption of Cr(VI) by RHA and MRH

$\mathrm{K}_{\mathrm{f}}$ and $\mathrm{n}$ are, respectively, determined from the intercept and slope of plotting in qe versus in $\mathrm{C}_{\mathrm{e}}$. The Freundlich parameters for the adsorption of $\mathrm{Cr}(\mathrm{VI})$ are also shown in Table 2.

\section{RESULTS AND DISCUSSION}

Effect of $\mathbf{p H}$ on adsorption: The $\mathrm{pH}$ of the solutions has been identified as the most important variable governing metal adsorption. This is partly due to the fact that hydrogen ions themselves are strong competing ions and partly that the solution $\mathrm{pH}$ influences the chemical speciation of the metal ions as well as the ionization of the functional groups onto the adsorbent surfaces (Kadirvelu and Namasivayam, 2003). Effects of $\mathrm{pH}$ on the 


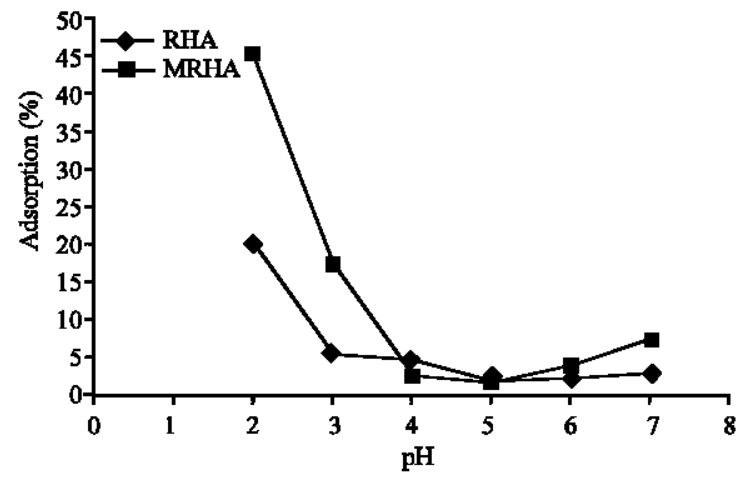

Fig. 3: Effect of $\mathrm{pH}$ on adsorption of $\mathrm{Cr}(\mathrm{VI})$ by $\mathrm{RHA}$ and MRHA

uptake capacities of $\mathrm{Cr}(\mathrm{VI})$ on RHA and MRHA were investigated. Experimental studies were carried out at the room temperature with initial $\mathrm{Cr}(\mathrm{VI})$ concentration $10 \mathrm{mg} \mathrm{L} \mathrm{L}^{-1}$ using adsorbent dosage (adsorbent size $250-500 \mu \mathrm{m}) 10 \mathrm{~g} \mathrm{~L}^{-1}$, agitation speed $120 \mathrm{rpm}$ for $30 \mathrm{~min}$. Moreover, hydroxide ions ( $\mathrm{OH}^{-}$ions $)$in the solution can bind with $\mathrm{Cr}(\mathrm{VI})$ ions to hydroxide complexes form solid so the system $\mathrm{pH}$ should not exceed 7 (2.0-7.0). The adsorption results are shown in Fig. 3.

From Fig 3, the results show that the $\operatorname{Cr}(\mathrm{VI})$ adsorption decreased with an increase of $\mathrm{pH}$. The maximum value of $\mathrm{Cr}(\mathrm{VI})$ retention occurred approximately at $\mathrm{pH}$ 2.0. At lower $\mathrm{pH}$, the biosorbent is positively charged due to protonation and dichromate ion exists as anion leading to an electrostatic attraction between them (Wasay et al., 1999). As $\mathrm{pH}$ is increases, deprotonation starts and thereby results in decrease of adsorption capacity. $\mathrm{Cr}(\mathrm{VI})$ forms stable complexes such as $\mathrm{Cr}_{2} \mathrm{O}_{7}{ }^{2-}$, $\mathrm{HCrO}_{4}, \mathrm{CrO}_{4}{ }^{-}$and $\mathrm{HCrO}_{7}$ depending on the $\mathrm{pH}$ of the solution. The fraction of any particular species depends upon the chromium concentration and $\mathrm{pH}$ of the solution (Namasivayam and Kadirvelu, 1999; Lee et al., 2005; Umesh et al., 2007). Moreover, adsorption of $\mathrm{Cr}$ (VI) by MRHA has been found to be higher than RHA. The fact that a base treatment can be remove surface impurities and expose available binding sites for metal bioadsorption after pretreatment, might be the reason for the increase in metal biosorption (Bhatti et al., 2007; Gerdoa-Torresdey et al., 2000).

Effect of contact time on adsorption: The rate of adsorption that takes place is one of the parameters for economical wastewater treatment plant application. Consequently, it is important to establish the time dependence of such systems under various process conditions (Patnukao et al., 2008). Effects of contact time on the removal of $\mathrm{Cr}(\mathrm{VI})$ are shown in Fig. 4. Experiment studies were carried out at the room temperature with

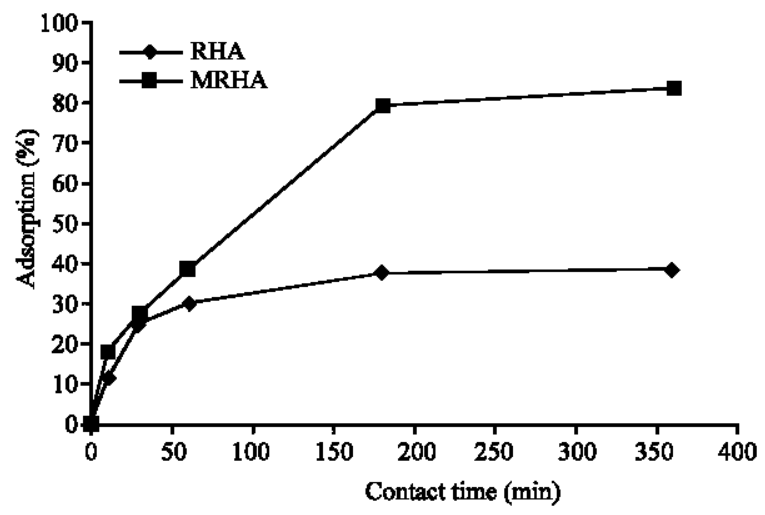

Fig. 4: Effect of contact time on adsorption of $\mathrm{Cr}$ (VI) by RHA and MRHA

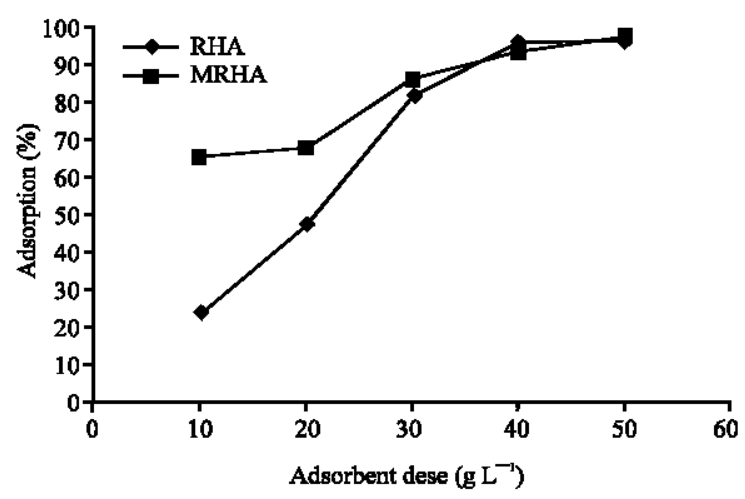

Fig. 5: Effect of adsorption dose on adsorption of $\mathrm{Cr}(\mathrm{VI})$ by RHA and MRHA

initial $\mathrm{Cr}(\mathrm{VI})$ concentration $10 \mathrm{mg} \mathrm{L}^{-1}$ using adsorbent dosage (adsorbent size 250-5600 $\mu \mathrm{m}$ ) $10 \mathrm{~g} \mathrm{~L}^{-1}$ at $\mathrm{pH} 2.0$ and agitation speed $120 \mathrm{rpm}$ for contact time $0,10,30,60$, 180 and $360 \mathrm{~min}$.

In Fig. 4, it shows that the rate of $\mathrm{Cr}(\mathrm{VI})$ adsorption is found to be very rapid gradually increase in the period time of $0-180$ min and thereafter, the removal of $\mathrm{Cr}(\mathrm{VI})$ ions is almost constant. During the initial stage of sorption, a large number of vacant surface sites are available for adsorption. After a lapse of some time, the remaining vacant surface sites have difficulty in becoming occupied due to repulsive forces between the adsorbate molecules on the solid surface and in the bulk phase. Besides, the metal ions are adsorbed into the mesopores that get almost saturated with $\mathrm{Cr}(\mathrm{VI})$ ions during the initial stage of adsorption ( $\mathrm{Lu}$ et al., 2009). In this study, the appropriate contact time for $\mathrm{Cr}(\mathrm{VI})$ adsorption on $\mathrm{RHA}$ and MRHA is $180 \mathrm{~min}$.

Effects of absorbent dose on adsorption: Effects of adsorbent dose on the removal of $\mathrm{Cr}(\mathrm{VI})$ are shown in Fig. 5. Experiment studies were carried out at the room 
temperature with $\mathrm{Cr}$ (VI) initial concentration $10 \mathrm{mg}^{-1}$ using adsorbent dosage (adsorption size $250-500 \mu \mathrm{m}$ ) 10, 20 , 30,40 and $50 \mathrm{~g} \mathrm{~L}^{-1}$ at $\mathrm{pH} 2.0$ and agitation speed $120 \mathrm{rpm}$ for $180 \mathrm{~min}$.

Figure 5 shows the adsorption of $\mathrm{Cr}$ (VI) as a function of RHA and MRHA dosages. It is apparent that increasing the adsorbent dose causes an increase in the amount of $\mathrm{Cr}$ (VI) but a decrease the amount adsorbed per unit mass, adsorption density. It is readily understood that the number of available adsorption sites increases by increasing the adsorbent dose and it, therefore, results in the increase of the amount of adsorbed $\mathrm{Cr}$ (VI) The decrease in adsorption density with increase in the adsorbent dose is mainly because of unsaturation of adsorption sites through the adsorption process ( $Y u$ et al., 2003; Pehlivan et al., 2008). Another reasons may be due to the particle interaction, such as aggregation, resulting from high adsorbent dose. Such aggregation would lead to decrease in total surface area of the adsorbent and an increase in diffusion path length (Shukla et al., 2002). The results can be concluded that the appropriate adsorbent dose is $40 \mathrm{~g} \mathrm{~L}^{-1}$. After this dose, the increasing rate of $\mathrm{Cr}(\mathrm{VI})$ removal is almost constant.

Effect of initial Cr(VI) concentration: Effects of initial $\mathrm{Cr}$ (VI) concentration on the removal of $\mathrm{Cr}$ (VI) was shows in Fig 6. Experiment studies were carried out at the room temperature with $\mathrm{Cr}(\mathrm{VI})$ initial concentration $10,15,20$ and $30 \mathrm{mg} \mathrm{L}^{-1}$ using adsorbent dosage (adsorption size $250-500 \mu \mathrm{m}) 40 \mathrm{~g} \mathrm{~L}^{-1}$ at $\mathrm{pH} 2.0$ and agitation speed $120 \mathrm{rpm}$ for $180 \mathrm{~min}$.

The effect of initial $\mathrm{Cr}$ (VI) concentration is also examined (Fig. 6) In the case of low concentrations, the ratio of the initial number of moles of $\mathrm{Cr}$ (VI) ions to the available surface area is larger and subsequently the fractional adsorption becomes independent of initial concentrations. The suitable initial $\mathrm{Cr}(\mathrm{VI})$ concentration is $10 \mathrm{mg} \mathrm{L}^{-1}$. At higher concentrations, the available sites of adsorption become decreased and hence the percentage adsorption of $\mathrm{Cr}$ (VI) decreases. It is readily understood that the number of available adsorption sites are inconstant but increasing the adsorbate.

Moreover, this research was repeated the adsorption capacity of RHA and MRHA at the optimal condition as $\mathrm{pH} \mathrm{2}$, contact time $180 \mathrm{~min}$, the room temperature, adsorbent size $250-500 \mu \mathrm{m}$, agitation speed $120 \mathrm{rpm}$, adsorbent dose $40 \mathrm{~g} \mathrm{~L}^{-1}$ and initial $\mathrm{Cr}$ (VI) concentration $10 \mathrm{mg} \mathrm{L}^{-1}$. In this condition, the adsorption ability RHA and MRHA are 59.12 and $81.39 \%$, respectively.

Sorption isotherms: Adsorption isotherms for adsorption of $\mathrm{Cr}$ (VI) on RHA and MRHA were calculated from the results of studying effects of initial $\mathrm{Cr}$ (VI) concentration.
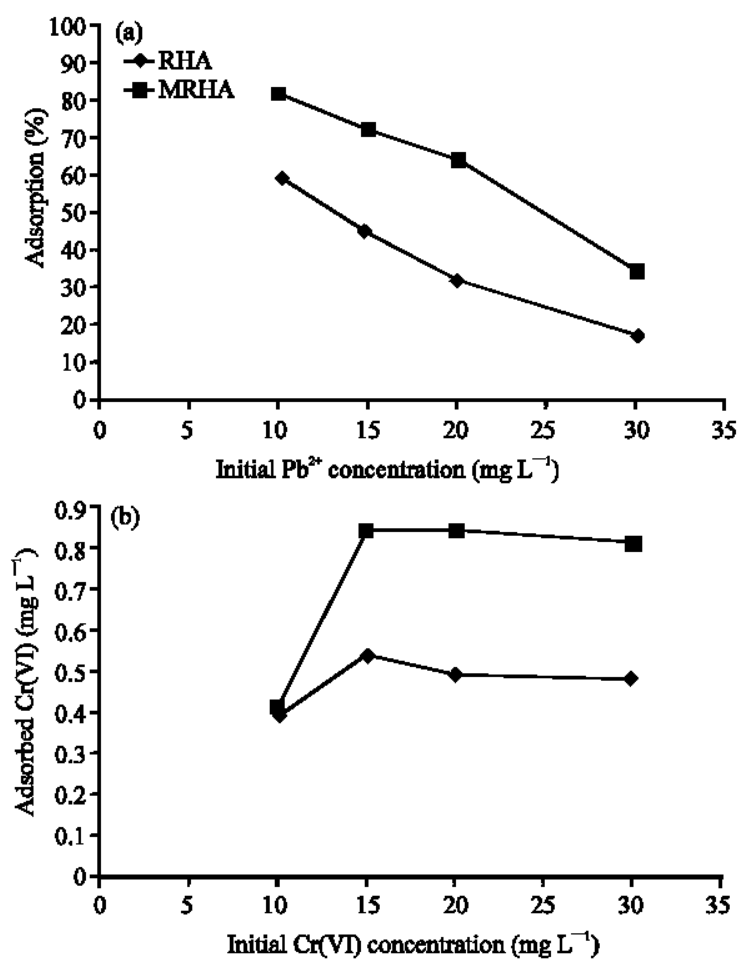

Fig. 6: (a) Effect of initial $\mathrm{Cr}(\mathrm{VI})$ concentration on adsorption of $\mathrm{Cr}$ (VI) by RHA and MRHA; (b) Effect of initial $\mathrm{Cr}(\mathrm{VI})$ concentration to adsorbed $\mathrm{Pb}^{2+}$

Table 3: Comparison between adsorption capacity of RHA and MRHA and other adsorbents

\begin{tabular}{lcl}
\hline & $\begin{array}{c}\text { Adsorbent capacity } \\
\left(\mathrm{mg} \mathrm{g}^{-1}\right)\end{array}$ & \multicolumn{1}{c}{ References } \\
\hline Absorbent & 0.28 & Daneshvar et al. $(2002)$ \\
Soya cake & 0.28 & Umesh et al. $(2007)$ \\
Jatropha comcob & 0.82 & Umesh et al. (2007) \\
Sugar cane bagasse & 0.63 & Umesh et al. $(2007)$ \\
Almond shell & 0.58 & Pehlivan et al. $(2008)$ \\
RHA & 0.49 & This study \\
MRHA & 0.84 & This study \\
\hline
\end{tabular}

The results present that the experiment data were better fitted to the Langmuir equation $\left(\mathrm{R}_{\mathrm{RHA}}^{2}=0.9962\right.$, $\left.\mathrm{R}_{\text {MRHA }}^{2}=0.9947\right)$ than the Freundlich equation $\left(\mathrm{R}_{\mathrm{RHA}}^{2}=\right.$ $0.9962, \mathrm{R}_{\mathrm{RHA}}^{2}=0.9947$ ) (Table 2).

From the results, the Langmuir adsorption model, based on the sorption on a homogeneous surface by monolayer sorption without interaction between sorbed species becomes more appropriate to describe the process.

Table 3 shows a comparison between the results of this research and others found in the literature. The values of $\mathrm{Cr}(\mathrm{VI})$ specific uptake found in this research were higher than the other excepted researchs. Thus, the RHA and MRHA are the effective absorbents for the $\mathrm{Cr}$ (VI) adsorption from aqueous solutions. 


\section{CONCLUSION}

Rice husk ash is an interesting alternative adsorbent for heavy metals because of its quantity and characteristics. Although, these results are presented that adsorption capacity is low but it is useful for alternative waste management programs and friendly with ecosystems. Moreover, it can increase the effectiveness of $\mathrm{Cr}$ (VI) adsorption from $\mathrm{RHA}$ by $\mathrm{NaOH}$ modification.

The results indicated that all adsorption parameters affected the adsorption of $\mathrm{Cr}(\mathrm{V})$ by RHA and MRHA. The adsorption ability of RHA and MRHA were 59.12 and $81.39 \%$ at $\mathrm{pH} \mathrm{2}$, contact time $180 \mathrm{~min}$, the room temperature, adsorbent size $250-500 \mu \mathrm{m}$, agitation speed $120 \mathrm{rpm}$, adsorbent dose $40 \mathrm{~g} \mathrm{~L}^{-1}$ and initial $\mathrm{Cr}(\mathrm{VI})$ concentration $10 \mathrm{mg} \mathrm{L}^{-1}$. Furthermore, the results were fitted to Langmuir isotherm better than Fruendlich isotherm.

Therefore, the adsorption mechanism based on the sorption on a homogeneous surface by monolayer sorption without interaction between sorbed species becomes more appropriate to describe this process. The adsorption capacity of RHA and MRHA were 0.49 and $0.84 \mathrm{mg} \mathrm{g}^{-1}$, respectively. Finally, the RHA and MRHA utilization is an alternative waste management or environmental conservation. All adsorption parameters as $\mathrm{pH}$, contact time, adsorbent does and initial $\mathrm{Cr}(\mathrm{VI})$ concentration can affect to the $\mathrm{Cr}(\mathrm{VI})$ adsorption by RHA and MRHA

\section{ACKNOWLEDGEMENTS}

The project sponsored by Faculty of Environment and Resource Studies, Mahasarakham University, Thailand. Moreover, this study is suggested about environmental techniques by Associate Professor Dr. Petch Pengchai, Faculty of Engineering, Mahasarakham University, Thailand.

\section{REFERENCES}

Aggarwal, D., M. Goyal and R.C. Bansal, 1999. Adsorption of chromium by activated carbon from aqueous solution. Carbon, 37: 1989-1997.

Bhatti, H.N., B. Mumtaz, M.A. Hanif and R. Nadeem, 2007. Removal of $\mathrm{Zn}(\mathrm{II})$ ions from aqueous solution using Moringa oleifera Lam (horseradish tree) biomass. Process Biochem., 42: 547-553.

Daneshvar, N., D. Salari and S. Aber, 2002. Chromium adsorption and $\mathrm{Cr}(\mathrm{VI})$ reduction to trivalent chromium in aques solutions by soya cake. J. Hazard. Mater., 94: 49-61.
Garg, V.K., R. Gupta, R. Kumar and R.K. Gupta, 2004. Adsorption of chromium from aqueous solution on treated sawdust. Bioresour. Technol., 92: 79-81.

Gerdoa-Torresdey, K.J., V. Tiemann, L. Armandariz and R.R. Bess-Oberte, 2000. Characterisation of $\mathrm{Cr}(\mathrm{VI})$ binding and reduction to $\mathrm{Cr}(\mathrm{III})$ by the agricultural by products Avena monida (Oat) biomass. J. Hazard. Mater., 80: 175-188.

Guo, S., W. Li, L. Zhang, J. Peng, H. Xia and S. Zhang, 2009. Kinetics and equilibrium adsorption study of lead (II) onto the low cost adsorbent-Eupatorium adenophorum spreng. Process Safety Environ. Prot., 87: $343-351$

Gupta, V.K. and I. Ali, 2004. Removal of lead and chromium from wastewater using bagasse fly ash-a sugar industry waste. J. Colloid Interface Sci., 271: 321-328.

Hughes, K., M.E. Meek, L.J. Seed and J. Shedden, 1994. Chromium and its compounds: Evaluation of risks to health from environmental exposure in Canada. J. Environ. Sci. Health, 12: 237-255.

Kadirvelu, K. and C. Namasivayam, 2003. Activated carbon from coconut coir pith as metal adsorbent: Adsorption of Cd (II) from aqueous solution. Adv. Environ. Res., 7: 471-478.

Karthikeyan, T., S. Rajgopal and L.R. Miranda, 2005. Chromium(VI) adsorption from aqueous solution by Hevea Brasilinesis sawdust activated carbon. J. Hazard. Mater., 124: 192-199.

Khatoon, S., J. Anwar, M. Hassan, R. Farooq, H.B. Fatima and H.N. Khalid, 2009. Removal of chromium (VI) by biosorption of eucalyptus bark. World Applied Sci. J., 6: 1638-1643.

Khezami, L. and R. Capart, 2005. Removal of Chromium(VI) from aqueous solution by activated carbons: Kinetic and equilibrium studies. J. Hazard. Mater., B1 23: 223-231.

Lee, M.Y., K.J. Hong, Y. Shin-Ya and T. Kejiuchi, 2005. Adsorption of hexavalent chromium by chitosan-based polymeric surfactants. J. Applied Polymer Sci., 96: 44-50.

Lu, D., Q. Cao, X. Cao and F. Luo, 2009. Removal of Pb(II) using the modified lawny grass: Mechanism, kinetics, equilibrium and thermodynamics studies. J. Hazard. Mater., 166: 239-247.

McCarron, P., I. Harvey, R. Brogen and T.J. Peters, 2000. Self reported health of people in an area contaminated by chromium waste: Interview study. BMJ., 320: 11-15.

Namasivayam, C. and K. Kadirvelu, 1999. Uptake of mercury (II) from wastewater by activated carbon from an unwanted agricultural solid by-product: Coirpith. Carbon, 37: 79-84. 
Patnukao, P., A. Kongsuwan and P. Pavasan, 2008. Batch studies of adsorption of copper and lead on activated carbon from Eucalyptus camaldulensis Dehn. Bark. J. Environ. Sci., 20: 1028-1034.

Pehlivan, E., T. Altun and S. Parlayici, 2008. Utilization of barley straws as biosorbents for $\mathrm{Cu}^{2+}$ and $\mathrm{Pb}^{2+}$ ions. J. Hazard. Mater., 164: 982-986.

Raji, C. and T.S. Anirudhan, 1997. Chromium removal by activated carbons prepared from Casuarina equisetifolia leaves. Bioresour. Technol., 73: 99-103.

Saueprasearsit, P., M. Naunjaroen and N. Chilapa, 2010. Biosorption of lead $\left(\mathrm{Pb}^{2+}\right)$ by luffa cylindrical fiber. Environ. Res. J., 4: 157-166.

Shukla, A., Y.H. Zhang, P. Dubey, J.L. Margrave and S.S. Shukla, 2002. The role of sawdust in the removal of unwanted materials from water. J. Hazard. Mater., B95: 137-152.
Singh, K.K., R. Rastogi and S.H. Hasan, 2005. Removal of $\mathrm{Cr}$ (VI) from wastewater using rice bran. J. Colloid Interfere Sci., 290: 61-68.

Tan, W.T., S.T. Ooi and C.K. Lee, 1993. Removal of Chromium(VI) from solution by coconut husk and palm pressed fibers. Environ. Technol., 14: 277-282.

Umesh, K., U.K. Garg, M.P. Kaur, V.K. Garg and D. Sud, 2007. Removal of hexavalent chromium from aqueous solution by agricultural waste biomass. J. Hazard. Mater., 140: 60-68.

Wasay, S.A., S. Barrinton and S. Tokunage, 1999. Efficiency of GAC for treatment of leachate from soil washing process. Water Air Soil Pollut., 116: 449-460.

Yu, L.J., S.S. Shukla, K.L. Dorrisa, A. Shuklab and J.L. Margrave, 2003. Adsorption of chromium from aqueous solutions by maple sawdust. J. Hazard. Mater., 100: 53-63. 